DOI 10.18551/rjoas.2019-05.08

\title{
MEASUREMENT MODEL OF BEHAVIORAL INTENTION TO SUBSCRIBE YOUTUBE CHANNEL CONTENT USING UTAUT 2 MODEL
}

\author{
Putri Marietta Krisnaya Nandika* \\ Magister Business School, Bogor Agricultural University, Indonesia \\ Simanjuntak Megawati, Yuliati Lilik Noor \\ Department of Family and Consumer Sciences, Faculty of Human Ecology, \\ Bogor Agricultural University, Indonesia \\ *E-mail: mariettakrisnayadesign@gmail.com
}

\begin{abstract}
This study research about measurement model of behavioral intention to subscribe YouTube Channel content named Kidz with SEM-PLS. Kidz is a Youtube Channel content that share videos for kids. The samples of this research were Kidz users aged 7-12 through online form. There are 11 latent variables and 72 manifest variables. Latent variable of this study are performance expectancy, effort expectancy, social influence, facilitating condition, hedonic motivation, habit, e-lifestyle, promotion, behavioral intention to use, usage behavior, and behavioral intention to subscribe. The result shows about the recommendation contribution of manifest variable to latent variable.
\end{abstract}

\section{KEY WORDS}

Behavioral intention, contribution, manifest variable, latent variable, subscribe, YouTube channel content.

Internet started entering Indonesia since 1990. In fact, for the time being, Indonesia became one of the biggest internet user's countries in the world. Based on data survey published by Asosiasi Penyelenggara Jasa Internet Indonesia (APJII), the growth of internet users reached 143.26 million from total 262 millions of Indonesian population. Internet users are increased for around 22.5 million users during 2015 to 2016, while in period 2016 to 2017 it increased for around 10.56 million users. The growth of Indonesia's internet users in 2017 presented in Figure 1.

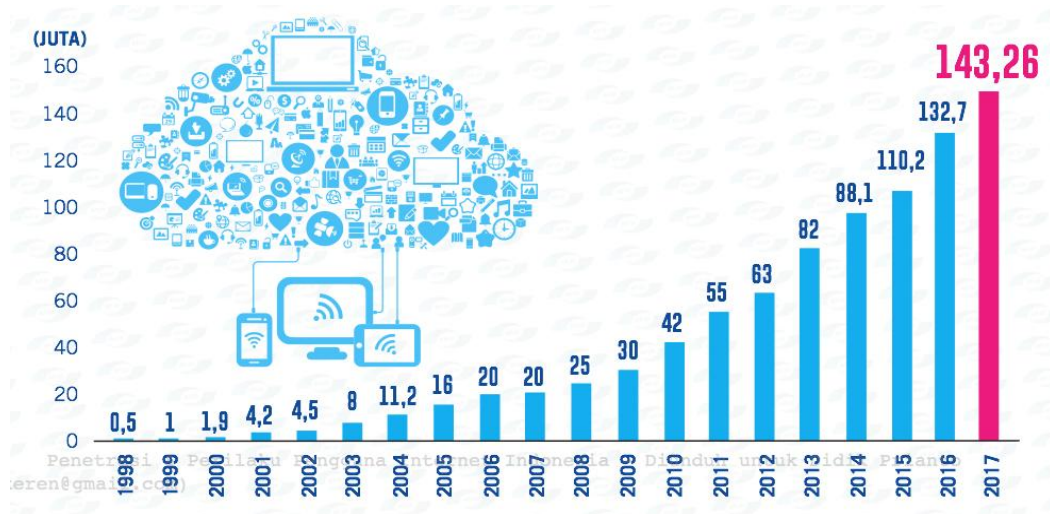

Figure 1 - The growth of Indonesia's internet users in 2017 (Source: APJII, 2017)

Internet is not only used as media of communication, but also maximize as a media of marketing. Social media is much used with internet in business activity too, since it becomes very popular way among modern society. One type of social media is YouTube. People use YouTube to get an entertainment, tutorial, product's review and information. It makes YouTube as a media to share many kinds of creative videos as tutorial, review product, 
entertain and informative. This phenomenon brings out business opportunities to make content in YouTube Channel. AXY Studio as a creator of Kidz content has been produced and published many kinds of interesting videos in YouTube. Until Feb $14^{\text {th }} 2019$, this content had already 111.274 subscribers.

Video that had been uploaded on YouTube Channel means it can bring the viewers. When the viewers are getting interests in one of the video, they possible to watch another similar video in the same content (Helianthusonfri 2014). The number of subscribers is very important because it can affect the reach of the video. The more subscriber joined the content, the more people will watch video on that content, means it will automatically increase the interaction occurs on the video. The interaction can be like, comments or even share. The more video shared, the more video being popular, and watched by many people.

Consumer behavior on finding an entertainment and product review in the right place are important thing for a content branding process. In previous research, there was an observed about consumer behavioral intention to subscribe some application music streaming service (Helkkula 2016). Helkkula was doing some of a research about the factors that affect behavioral intention to subscribe music streaming service application. It used UTAUT2 as a model of the research and the effect of behavioral intention.

Keushen as a Managing Director of Google Indonesia said that YouTube consumption in Indonesia has been increase in 2017. It can be seen from watching duration that reached until one million hour. The number of uploaded video by local creator was increase significantly. In 2016, YouTube has an increase in watching duration 155 percent and uploading video 279 percent. YouTube then has a commitment to support the growth of Indonesian content creators.

Indonesian smartphone users which are 30 percent of total population are watching video from internet (smartphone, tablet, or computer) more often than from televison. YouTube give an opportunity for every creator to make a creative content. Keusgen predicted that gadget technology growth with affordable price, and easy to use will make a quality of YouTube content video similar with the quality of television or movie content. Social media, including YouTube, is a democracy technology facility that erase barrier of entry in creativity world. To share creativity, a creator was not have to rely to the conventional media like television.

Based from their official website, YouTube has a program named YouTube Partnership Program. This program was made to every people that want become a permanent creator of YouTube. To join this program, creator should have a Google account and Adsense account for payment. Next, a creator should have some videos, viewing activity, viewers, and subscribers that increase consistantly. A creator that has be a member of YouTube Partnership Program will get profit (money) from advetisement and showing activity (Labas and Yasmine 2017). Based on the growth of social media, author makes a research about the factors that affect behavioral intention to subscribe YouTube Channel content.

The model of this study used UTAUT2. There are 11 latent variables, such as performance expectancy, effort expectancy, social influence, facilitating condition, hedonic motivation, habit, e-lifestyle, promotion, behavioral intention to use, usage behavior, and behavioral intention to subscribe. The purpose of this research is to analyse factors that affect behavioral intention to use content and behavioral intention to subscribe YouTube Channel by knowing the contribution of manifest variable to latent variable.

\section{METHODS OF RESEARCH}

Data collection was conducted over four months (May-August 2018). The approaching used in this research is quantitative research with associate method. The samples of this research were Kidz users, age 7-12 years old. This study used non probability sampling and convenience sampling technique. All respondents were given an online questionnaire by google form. Likert was used as a measurement scale. Technique dataprocess that used in this research is SEM-PLS and description analysis by PLS 3.0 software. 


\section{RESULTS AND DISCUSSION}

There are five manifest variable of performance expectancy, such as a good video (PE1), the comprehensive information in description box (PE2), the clarity of content video (PE3), the quality of video images (PE4), the interest of content video (PE5). All relationship among manifest variable and latent variable are valid. Loading factor value of performance expectancy (before and after elimination) presents at Table 1.

Table 1 - Loading factor value of perfomance expectancy

\begin{tabular}{llll}
\hline Indicator Variable & Loading Factor & T Statistic & Description \\
\hline Good video cover (PE1) & 0.563 & 6.096 & Valid \\
Comprehensive information in description box (PE2) & 0.777 & 14.467 & Valid \\
Clarity of content video (PE3) & 0.745 & 12.515 & Valid \\
Quality of video images (PE4) & 0.595 & 6.698 & Valid \\
Interest of content video (PE5) & 0.816 & 21.797 & Valid \\
\hline
\end{tabular}

Base on the result, a sequence of manifest variable that have a contribution from highest to lowest are the interest of content video (PE5) with loading factor value 0.816, the comprehensive information in description box (PE2) with loading factor value 0.777 , the clarity of content video (PE3) with loading factor value 0.745 , the quality of video images (PE4) with loading factor value 0.595 , and a good video cover (PE1) with loading factor value 0.563. The interest of content video as a highest contribution for performance expectancy becomes a consideration of content users to enjoy Kidz channel better than another channel. Kidz always maintain the quality of video so the viewers will be enjoyed.

Effort expectancy expectancy have a three manifest variable, such as understanding how to operate content (EE2), clarity knobs information (EE2), and Easy to study content (EE3). All relationship among manifest variable and latent variable are valid. Loading factor value of effort expectancy (before and after elimination) presents at Table 2.

Table 2 - Loading factor value of effort expectancy

\begin{tabular}{llll}
\hline Indicator Variable & Loading Factor & T Statistic & Description \\
\hline Understanding how to operate content (EE1) & 0.916 & 5.595 & Valid \\
Clarity knobs information (EE2) & 0.900 & 5.317 & Valid \\
Easy to study content (EE3) & 0.941 & 6.777 & Valid \\
\hline
\end{tabular}

Base on the result, a sequence from the highest to lower contribution of manifest variable are easy to study content (EE3) with loading factor value 0.941 , understanding how to operate content (EE1) with loading factor value 0.916 , and clarity knobs information (EE2) with loading factor value 0.900 . Easy to study content as the highest contribution of effort expectancy giving a meaning that information to use content from YouTube are easy, so the users can maximize all the content facilities.

There are 16 manifest variable of social influence, such as parents recommendation to like content video (SI2), parents recommendation to comment content video (SI3), parents recommendation to share content video (SI4), siblings recommendation to watch content video (SI5), siblings recommendation to like content video (SI6), siblings recommendation to comment content video (SI7), siblings recommendation to share content video (SI8), friends recommendation to watch content video (SI9), friends recommendation to like video content (SI10), friends recommendation to comment video content (SI11), friends recommendation to share video content (SI12), Kidz actor/actress recommendation to watch content video (SI17), another youtuber recommendation to like content video (SI18), another youtuber recommendation to comment content video (SI9), and another youtuber recommendation to share content video (SI20). Loading factor value of social influence (before and after elimination) presents at Table 3.

In Table 3, four manifest variable of social media that have highest contribution are parents recommendation to share content video (SI4) with loading factor value 0.848 , another youtuber recommendation to share content video (SI20) with loading factor value 
0.847, another youtuber recommendation to comment content video (SI19) with loading factor value 0.838 , and another youtuber recommendation to like content video (SI18) with loading factor value 0.837 . The parents of users are affecting behavioral intention their kids to share Kidz video they like most in social media. Share means a recommendation video from content users to their friends in social media. The more sharing video activity happened, the most it confirmed that the video content is recommended to be watched and enjoyed by everybody.

Table 3 - Loading factor value of social influence

\begin{tabular}{llll}
\hline Indicator Variable & Loading Factor & T Statistic & Description \\
\hline Parents recommendation to like content video (SI2) & 0.601 & 10.516 & Valid \\
Parents recommendation to comment content video (SI3) & 0.673 & 9.628 & Valid \\
Parents recommendation to share content video (SI4) & 0.848 & 27.779 & Valid \\
Siblings recommendation to watch content video (SI5) & 0.554 & 6.657 & Valid \\
Siblings recommendation to like content video (SI6) & 0.644 & 8.520 & Valid \\
Siblings recommendation to comment content video (SI7) & 0.648 & 8.057 & Valid \\
Siblings recommendation to share content video (SI8) & 0.827 & 16.249 & Valid \\
Friends recommendation to watch content video (SI9) & 0.576 & 6.004 & Valid \\
Friends recommendation to like content video (SI10) & 0.634 & 7.596 & Valid \\
Friends recommendation to comment content video (SI11) & 0.679 & 7.879 & Valid \\
Friends recommendation to share content video (SI12) & 0.753 & 10.984 & Valid \\
Kidz actor/actress recommendation to share content video (SI16) & 0.595 & 8.392 & Valid \\
Another youtuber recommendation to watch content video (SI17) & 0.781 & 15.102 & Valid \\
Another youtuber recommendation to like content video (SI18) & 0.837 & 25.903 & Valid \\
Another youtuber recommendation to comment content video (SI19) & 0.838 & 23.872 & Valid \\
Another youtuber recommendation to share content video (SI20) & 0.847 & 23.671 & Valid \\
\hline
\end{tabular}

Facilitating condition have three manifest variable, such as the availability of internet (FC1), the availability of computer/laptop (FC2), and the availability of smartphone (FC3). All relationship among manifest variable and latent variable are valid. Loading factor value of performance expectancy (before and after elimination) presents at Table 4.

Table 4 - Loading factor value of facilitating condition

\begin{tabular}{llll}
\hline Indicator Variable & Loading Factor & T Statistic & Description \\
\hline The availability of internet (FC1) & 0.741 & 7.953 & Valid \\
The availability of computer/laptop (FC2) & 0.788 & 8.225 & Valid \\
The availability of smartphone (FC3) & 0.835 & 11.850 & Valid \\
\hline
\end{tabular}

Base on the result, the highest contribution manifest variable is the availability of smartphone (FC3) with loading factor value 0.835 . Next, the availability of computer/laptop (FC2) with loading factor value 0.788 , and the availability of internet (FC1) with loading factor value 0.741 . The availability of a smartphone unit has been enough for content user to enjoy Kidz video. Smartphone more simple, easily to use, and little bit cheap, so it is possible for everybody to have it and bring it everywhere, everytime.

There are three manifest variables on hedonic motivation, such as content video is fun (HM1), content video is enjoyable (HM2), and fun intrection (HM3). All relationship among manifest variable and latent variable are valid. Loading factor value of performance expectancy (before and after elimination) presents at Table 5.

In Table 5, a sequence of manifest variable that have a contribution from highest to lowest are content video is fun (HM1) with loading factor value 0.892 , content video is enjoyable (HM2) with loading factor value 0.878, and fun interaction (HM3) with loading factor value 0.615 . The higher manifest variable is a pleasurable feeling fun interaction when watching Kidz video. That feeling affect behavioral intention to use Kidz content.

There are eight manifest variable in habbit, such as addicted to open content $(\mathrm{H} 1)$, addict to watch content video $(\mathrm{H} 2)$, addict to like content video $(\mathrm{H} 3)$, addict to comment content video $(\mathrm{H} 4)$, addict to share content video $(\mathrm{H} 5)$, directly watch a new video $(\mathrm{H} 6)$, know the new video uploaded schedule $(\mathrm{H} 7)$, and repeat to watch the same video (H8). All relationship among manifest variable and latent variable are valid. Loading factor value of performance expectancy (before and after elimination) presents at Table 6. 
Table 5 - Loading factor value of hedonic motivation

\begin{tabular}{llll}
\hline Indicator Variable & Loading Factor & T Statistic & Description \\
\hline Content video is fun (HM1) & 0.892 & 41.057 & Valid \\
Content video is enjoyable (HM2) & 0.878 & 27.155 & Valid \\
Fun interaction (HM3) & 0.615 & 6.221 & Valid \\
\hline
\end{tabular}

Table 6 - Loading factor value of habit

\begin{tabular}{llll}
\hline Indicator Variable & Loading Factor & T Statistic & Description \\
\hline Addict to open content $(\mathrm{H} 1)$ & 0.768 & 15.348 & Valid \\
Addict to watch content video $(\mathrm{H} 2)$ & 0.814 & 21.874 & Valid \\
Addict to like content video $(\mathrm{H} 3)$ & 0.813 & 23.819 & Valid \\
Addict to comment content video $(\mathrm{H} 4)$ & 0.817 & 18.953 & Valid \\
Addict to share content video $(\mathrm{H} 5)$ & 0.744 & 16.489 & Valid \\
Directly watch a new video $(\mathrm{H} 6)$ & 0.820 & 24.835 & Valid \\
Know the new video uploaded schedule $(\mathrm{H} 7)$ & 0.663 & 8.831 & Valid \\
Repeat to watch the same video $(\mathrm{H} 8)$ & 0.776 & 19.639 & Valid \\
\hline
\end{tabular}

Base on Table 6, two manifest variable that has a highest contribution are directly watch a new video $(\mathrm{H} 6)$ with loading factor value 0.820 and addict to comment content video $(\mathrm{H} 4)$ with loading factor 0.817 . The way that can be taken by creator to increase habit are creating a routine and consistant schedule on uploading new video, so the viewers know the new video uploaded schedule. The fix schedule will create the habit. In line with that, addict to comment video means that Kidz users are often comment Kidz videos. They comment about variety of toys, quality of performance Kidz actor or actress, the answer of question from Kidz actor or actress on video, etc.

E-lifestyle has three manifest variables, such as access internet with smartphone (EL1), interest to use internet (EL3), and the existence of internet that helps daily activity (EL4). Loading factor value of performance expectancy (before and after elimination) presents at Table 7.

Table 7 - Loading factor varibel e-lifestyle

\begin{tabular}{llll}
\hline Indicator Variable & Loading Factor & T Statistic & Description \\
\hline Access internet with smartphone (EL1) & 0.831 & 2.889 & Valid \\
Interest to use internet (EL3) & 0.882 & 3.139 & Valid \\
The existence of internet that helps daily activity (EL4) & 0.773 & 2.438 & Valid \\
\hline
\end{tabular}

Base on Table 7, a sequence of manifest variable that have a contribution from highest to lowest are interest to use internet (EL3) with loading factor value 0.831 , access internet with smartphone (EL1) with loading factor value 0.831, and the existence of internet that helps daily activity (EL4) with loading factor value 0.773 . In e-lifestyle, the highest contribution manifest variable is interest conternt users to use internet (EL3). This feeling create a profit for Kidz which is based online with internet.

Promotion has four manifest variable, such as a good promotion banner (PR1), recommendation to watch from another social media (PR2), giveaway quiz (PR4), and impression live video (PR5). Loading factor value of performance expectancy (before and after elimination) presents at Table 8.

In Table 8, a sequence of manifest variable that have a contribution from highest to lowest are impression live video (PR5) with loading factor value 0.786 , recommendation to watch from social media (PR2) with loading factor value 0.778 , a good promotion banner (PR1) with loading factor 0.657, and giveaway quiz (PR5) with loading factor value 0.786 . The highest contribution manifest variable of promotion is about the interest of Kidz users with Kidz live video from on other social media (Facebook). Live video shares about behind the scene of Kidz video or live interaction between actor and actress Kidz with Kidz users and viewers. In live video the actor or actress can directly answer the question from viewers, so it makes the viewers more happily.

There are ten manifest variable of behavioral intention to use, such as intention to open content (BITO1), intention to watch content video (BITO2), intention to like content video 
(BTO3), intention to comment content video (BITO4), intention to share content video (BITO5), plan to open content (BITO6), plan to watch content video (BITO7), plan to like content video (BITO8), plan to cpmment content video (BITO9), and plan to share content video (BITO10). All relationship among manifest variable and latent variable are valid. Loading factor value of performance expectancy (before and after elimination) presents at Table 9.

Table 8 - Loading factor value of promotion

\begin{tabular}{llll}
\hline Indicator Variable & Loading Factor & T Statistic & Description \\
\hline A good promotion banner (PR1) & 0.657 & 8.549 & Valid \\
Recommendation to watch from another social media (PR2) & 0.778 & 11.604 & Valid \\
Giveaway Quiz (PR4) & 0.748 & 14.377 & Valid \\
Impression live video (PR5) & 0.786 & 15.529 & Valid \\
\hline
\end{tabular}

Table 9 - Loading factor of behavioral intention to use

\begin{tabular}{llll}
\hline Indicator Variable & Loading Factor & T Statistic & Description \\
\hline Intention to open content (BITO1) & 0.858 & 25.945 & Valid \\
Intention to watch content video (BITO2) & 0.817 & 21.688 & Valid \\
Intention to like content video (BITO3) & 0.862 & 29.104 & Valid \\
Intention to comment content video (BITO4) & 0.824 & 23.494 & Valid \\
Intention to share content video (BITO5) & 0.840 & 24.883 & Valid \\
Plan to open content (BITO6) & 0.845 & 24.010 & Valid \\
Plan to watch content video (BITO7) & 0.766 & 14.219 & Valid \\
Plan to like content video (BITO8) & 0.876 & 30.193 & Valid \\
Plan to comment content video (BITO9) & 0.875 & 39.789 & Valid \\
Plan to share content video (BITO10) & 0.860 & 32.594 & Valid \\
\hline
\end{tabular}

In Table 9, four manifest variable which has the highest contribution are plan to like content video (BITO8) with loading factor 0.876 , plan to comment content video (BITO9) with loading factor value 0.875 , intention to like content video (BITO3) with loading factor value 0.862 , and plan to share content video (BITO10) with loading factor 0.860 . The highest contribution manifest variable of behavioral intention to use gives an information that Kidz users have a plan to like Kidz video. They are happy, enjoy, and they get a new information from video.

Table 10 - Loading factor value of usage behavior

\begin{tabular}{llll}
\hline Indicator Variable & Loading Factor & T Statistic & Description \\
\hline Often to open content (UB1) & 0.842 & 32.918 & Valid \\
Often to watch content video (UB2) & 0.854 & 33.011 & Valid \\
Often to like content video (UB3) & 0.779 & 13.509 & Valid \\
Often to comment content video (UB4) & 0.744 & 11.533 & Valid \\
Often to share content video (UB5) & 0.739 & 12.544 & Valid \\
Often to watch video "Top model Penghias Wajah" (UB6) & 0.802 & 20.406 & Valid \\
Often to watch video "Es Kepal Milo Viral" (UB7) & 0.756 & 15.041 & Valid \\
Often to watch video "Tobot Z Bersama Kak Bella" (UB8) & 0.672 & 9.961 & Valid \\
Often to watch video "Monster Slime Cokelat" (UB9) & 0.771 & 14.629 & Valid \\
Often to watch video "Timun Mas Dongeng Rakyat Jawa Tengah" & 0.822 & 22.332 & Valid \\
(UB10) & & & \\
\hline
\end{tabular}

Ten manifest variable of usage behavior such as often to open content (UB1), often to watch content video (UB2), Often to like content video (UB3), Often to comment content video (UB4), Often to share content video (UB5), Often to watch video "Top model Penghias Wajah" (UB6), Often to watch video "Es Kepal Milo Viral" (UB7), Often to watch video "Tobot Z Bersama Kak Bella" (UB8), Often to watch video "Monster Slime Cokelat" (UB9), and Often to watch video "Timun Mas Dongeng Rakyat Jawa Tengah" (UB10). Loading factor value of performance expectancy (before and after elimination) presents at Table 10.

Based on Table 10, two highest contribution manifest variable of usage behavior are often to watch content video (UB2) with loading factor value 0.854 and often to open contwnt (UB1) with loading factor 0.842 . The next contribution are Often to watch video "Timun Mas 
Dongeng Rakyat Jawa Tengah" (UB10) with loading factor value 0.822 , Often to watch video "Top model Penghias Wajah" (UB6) with loading factor value 0.802, Often to like content video (UB3) with loading factor value 0.779 , Often to watch video "Monster Slime Cokelat" (UB9) with loading factor value 0.771 , Often to watch video "Es Kepal Milo Viral" (UB7) with loading factor value 0.756 , Often to comment content video (UB4) with loading factor value 0.744 , Often to share content video (UB5) with loading factor value 0.739 , and Often to watch video "Tobot Z Bersama Kak Bella" (UB8) with loading factor value 0.672.

There are two manifest variable of behavioral intention to subscribe, such as intention to subscribe content (SS1) and plan to subscribe content (SS2). Loading factor value of behavioral intention to subscribe (before and after elimination) present at Table 11.

Tablel 11 - Loading factor value of behavioral intention to subscribe

\begin{tabular}{llll}
\hline Indicator Variable & Loading Factor & T Statistic & Description \\
\hline Intention to subscribe content (SS1) & 0.955 & 95.208 & Valid \\
Plan to subscribe content (SS2) & 0.938 & 38.860 & Valid \\
\hline
\end{tabular}

In Table 11, all relationship among manifest variable and latent variable in behavioral intention to subscribe are valid. Intention to subscribe content (SS1) with loading factor value 0.955 is higher than plan to subscribe content (SS2) with loading factor 0.938 . It means that behavioral intention to subscribe Kidz content has a higher contribution than plan to subscribe Kidz content.

\section{CONCLUSION AND RECOMMENDATIONS}

This research found the important manifest variable as a base of forming behavioral intention to subscribe. Manifest variable that affect in UTAUT2 are the level of respondent trust of a good video cover, comprehensiveness of information, clarity of content video, quality of video images, interest of content video, level of understanding how to operate content, clarity knobs information, easy to study content, recommendation from parents, siblings, friends, Kidz actor or actress, and another youtuber to watch, like, comment, and share content video, availability of internet, computer or laptop, smartphone, happy and enjoy feeling from fun video and interaction, addict to open, watch, like, comment, and share video content, directly watch a new video, know the new video uploaded schedule, and repeat to watch the same video, access internet with smartphone, interest to use interner existence of internet that helps daily activities, a good promotion banner, recommendation to each from another social media, giveaway quiz, impression live video, intention to open, watch, like, comment, and share content video, plan to open, watch, like, comment, and share content video, often to open, watch, like, comment, and share video content, intention and plan to subscribe content. All manifest variables are recommended for UTAUT2 related of YouTube Channel content subscribe.

\section{REFERENCES}

1. [APJII] Asosiasi Penyelenggara Internet Indonesia. 2017. Penetrasi dan perilaku pengguna internet Indonesia 2017 [internet]. Tersedia pada: https://apjii.or.id/

2. Helkkula A. 2016. Consumer's intention to subscribe to music streaming service [tesis]. Finlandia (FI): Aalto University

3. Helianthusonfri J. 2014. YouTube Marketing. Jakarta (ID): PT. Gramedia.

4. [YouTube] Asta and Kidz. 2018. Home [internet]. [Diakses pada: 2018 Fbruari 5]. Tersedia pada https://www.youtube.com/channel/UCIrspzn-LEl1IS7PP6J2Dyw

5. YouTube. About [internet]. Tersedia pada https://www.youtube.com/yt/creators/

6. YouTube. Kebijakan dan Keamanan [internet]. [Diakses pada 2019 Maret 11]. Tersedia pada https://www.youtube.com/intl/id/yt/about/policies/\#community-guidelines/

7. YouTube. Tingkat Manfaat [internet]. [Diakses pada: 2019 Maret 11]. Tersedia pada https://www.youtube.com/intl/id/creators/benefits/ 